\title{
Penentuan Metode Pematahan Dormansi Benih Kecipir (Psophocarpus tetragonolobus L.) Aksesi Cilacap
}

\section{Determination Dormancy Breaking Method of Winged Bean Seed (Psophocarpus tetragonolobus L.) Cilacap Accession}

\author{
Nur Melasari, Tatiek Kartika Suharsi", dan Abdul Qadir \\ Departemen Agronomi dan Hortikultura, Fakultas Pertanian, Institut Pertanian Bogor \\ (Bogor Agricultural University), Jl. Meranti, Kampus IPB Darmaga, Bogor 16680, Indonesia \\ Telp. \& Faks.62-251-8629353 e-mail agronipb@indo.net.id \\ *Penulis Korespondensi : tsuharsi@yahoo.co.id
}

Disetujui : 15 Januari 2018 / Published Online 23 Januari 2018

\begin{abstract}
Winged bean is a plant that has many benefits and potential to preserved. The characteristics of winged bean seed that impermeable to water and gas are factors thought to cause winged difficult to germinate. This research aims to studied the effectiveness of dormancy breaking methods and their effects on the structure of winged bean seed. This research was conducted at IPB Seed Storage and Seed Quality Testing Laboratory and SEAMEO BIOTROP Silviculture Laboratory for 6 months. Dormancy breaking methods by treatment with a strong acid solution of 5\% $\mathrm{HNO}_{3}$ for 10 minutes with the germination value 93.33\% and the simultaneity growing value $86.67 \%$ is a method that can increase the germination and simultaneity growing percentage of winged bean seed. Treatment by a strong acid solution $\mathrm{HNO}_{3} 10 \%$ for 15 minutes with the index vigor value $56.67 \%$ is a treatment that can increase the index vigor percentage of winged bean seed. Treatment by temperature or $50{ }^{\circ} \mathrm{C}$ for 10 minutes with the grow rate value $14.79 \%$ etmal $^{-1}$ is a treatment that can increase the grow rate and produce sprouts with longer root than the control and other treatment. Treatment by sandpaper can not repair both viability and vigor, more over appaer the growth of fungi that cause seed deterioration.
\end{abstract}

Keywords : impermeable tissue, strong acid treatment, temperature treatment, viability, vigor

\section{ABSTRAK}

Kecipir merupakan tanaman yang mempunyai banyak manfaat dan berpotensi untuk dilestarikan. Karakteristik benih kecipir yang impermeabel terhadap air dan gas merupakan faktor yang diduga menyebabkan kecipir sulit untuk berkecambah. Penelitian ini bertujuan untuk mempelajari efektivitas metode pematahan dormansi dan pengaruhnya terhadap struktur benih kecipir. Penelitian dilaksanakan di Laboratorium Ilmu dan Teknologi Benih IPB dan Laboratorium Silvikultur SEAMEO BIOTROP selama 6 bulan. Metode pematahan dormansi dengan perlakuan larutan asam kuat $\mathrm{HNO}_{3} 5 \%$ selama 10 menit dengan nilai daya berkecambah $93.33 \%$ dan keserempakan tumbuh $86.67 \%$ merupakan nilai yang nyata lebih baik dibanding kontrol sehingga metode ini dapat meningkatkan persentase daya berkecambah dan keserempakan tumbuh benih kecipir. Perlakuan larutan asam kuat $\mathrm{HNO}_{3}$ 10\% selama 15 menit dengan nilai indeks vigor $56.67 \%$ merupakan perlakuan yang dapat meningkatkan persentase indeks vigor benih kecipir. Perlakuan suhu $50{ }^{\circ} \mathrm{C}$ selama 10 menit dengan nilai kecepatan tumbuh $14.79 \%$ etmal $^{-1}$ merupakan perlakuan yang dapat meningkatkan kecepatan tumbuh dan menghasilkan kecambah dengan akar yang lebih panjang dibandingkan kontrol maupun perlakuan lain. Perlakuan amplas tidak dapat meningkatkan viabilitas maupun vigor benih, bahkan menimbulkan pertumbuhan cendawan yang menyebabkan kemunduran benih.

Kata kunci : jaringan impermeabel, perlakuan asam kuat, perlakuan suhu tinggi, viabilitas, vigor 


\section{PENDAHULUAN}

Kecipir (Psophocarpus tetragonolobus L.) merupakan tanaman dari famili Leguminosae (kacang-kacangan) yang seluruh bagian tanamannya selain batang dapat dimanfaatkan. Kecipir mempunyai potensi yang baik untuk dikembangkan dan dilestarikan keberadaannya, akan tetapi pengembangan tanaman ini mempunyai kendala karena benihnya yang sulit untuk dikecambahkan. Karakteristik benih yang impermeabel terhadap air dan gas merupakan faktor yang diduga menyebabkan benih sulit untuk berkecambah, sehingga muncul sifat dormansi.

Dormansi merupakan suatu kondisi dimana benih hidup tidak berkecambah sampai batas waktu akhir pengamatan perkecambahan walaupun faktor lingkungan optimum untuk perkecambahannya (Widajati et al., 2013). Sifat dormansi benih dapat dipatahkan melalui perlakuan pematahan dormansi. Perlakuan pematahan dormansi adalah istilah yang digunakan untuk proses atau kondisi yang diberikan guna mempercepat perkecambahan benih. Perlakuan pematahan dormansi dapat dilakukan melalui skarifikasi secara mekanik dan kimia maupun stratifikasi (Widhityarini et al., 2011).

Skarifikasi mekanis merupakan metode yang sesuai sebagai perlakuan pematahan dormansi pada benih impermeabel, namun masih dianggap kurang efektif karena membutuhkan tenaga kerja yang banyak untuk skala besar dan pekerjaannya kurang sederhana dibandingkan dengan perlakuan kimia maupun perlakuan suhu (Astari et al., 2014). Bahan kimia yang sering digunakan dalam perlakuan pematahan dormansi diantaranya adalah asam $\mathrm{H}_{2} \mathrm{SO}_{4}, \mathrm{HCl}, \mathrm{HNO}_{3}$, serta garam $\mathrm{KNO}_{3}$ sedangkan suhu berkisar antara 40 ${ }^{0} \mathrm{C}-80{ }^{0} \mathrm{C}$. Penelitian mengenai metode pematahan dormansi merupakan informasi yang penting untuk menentukan metode yang tepat sebagai metode pematahan dormansi benih kecipir agar dapat memperbaiki viabilitas dan vigor benih.

\section{METODE PENELITIAN}

Penelitian dilaksanakan di Laboratorium Ilmu dan Teknologi Benih, Departemen Agronomi dan Hortikultura, Fakultas Pertanian, IPB untuk pemberian perlakuan pada benih, rumah kaca di Kebun Percobaan Leuwikopo, IPB untuk perkecambahan benih dan Laboratorium Silvikultur, SEAMEO BIOTROP untuk pembuatan preparat benih. Penelitian dilaksanakan pada Desember 2015 sampai dengan bulan Juni 2016. Bahan yang digunakan adalah benih kecipir aksesi Cilacap yang telah ditanam di Bogor dan dipanen pada bulan September 2015, larutan $\mathrm{H}_{2} \mathrm{SO}_{4}$, larutan $\mathrm{HCl}$, larutan $\mathrm{HNO}_{3}$, air panas, akuades, pasir, natrium hipoklorit. Bahan yang digunakan untuk pembuatan preparat kulit benih kecipir adalah larutan FAA, alkohol, larutan xylol, parafin, pewarna safranin dan metilen blue, serta gliserin. Alat yang digunakan meliputi autoklaf, bak tanam, timbangan, desikator, oven, termometer, cawan oven, gelas ukur, amplas, sendok pengaduk, label, pinset, scapel, cawan petri, silet, mikrotom, gelas objek, mikroskop, dan kamera.

Rancangan percobaan yang digunakan dalam penelitian adalah Rancangan Kelompok Lengkap Teracak (RKLT) satu faktor yaitu perlakuan pematahan dormansi dengan 38 taraf. Taraf terdiri dari kontrol, skarifikasi mekanik menggunakan kertas amplas, skarifikasi kimia menggunakan asam kuat $\mathrm{H}_{2} \mathrm{SO}_{4}, \mathrm{HNO}_{3}$, dan $\mathrm{HCl}$ dengan konsentrasi $5 \%, 10 \%$, dan $15 \%$ selama 5 menit, 10 menit, dan 15 menit, dan stratifikasi menggunakan air suhu $40{ }^{\circ} \mathrm{C}, 50{ }^{\circ} \mathrm{C}$, dan $60{ }^{\circ} \mathrm{C}$ dengan waktu perendaman 5 menit, 10 menit, dan 15 menit pada masing-masing suhu. Masingmasing taraf diulang sebanyak tiga kali sehingga secara keseluruhan terdapat 114 satuan percobaan. Data hasil pengamatan dianalisis menggunakan uji $F$, jika terdapat hasil yang berbeda nyata maka analisis dilanjutkan dengan uji lanjut Duncan Multiple Range Test (DMRT) dengan taraf 5\%.

Pelaksanaan penelitian diawali dengan sortasi benih kecipir secara manual, benih yang digunakan adalah benih berwarna testa hitam dan coklat tua dengan ukuran yang seragam. Sebelum dikecambahkan benih disterilkan dengan merendamnya dalam larutan natrium hipoklorit $5.25 \%$ selama 5 menit sebelum perlakuan dan 10 detik setelah perlakuan. Ulangan dilakukan pada waktu penanaman yang berbeda. Benih ditanam dalam bak dengan media pasir yang telah disterilkan, dimana satu bak ditanam 20 benih kecipir. Bak diletakkan di dalam rumah kaca dengan kondisi lingkungan yang sesuai untuk perkecambahan benih kecipir.

Perlakuan skarifikasi mekanis dilakukan dengan cara melukai kulit benih menggunakan kertas amplas. Pengamplasan dilakukan sampai testa berwarna keputihan pada tiga titik yaitu bagian samping kanan, bagian samping kiri, dan bagian bawah benih. Perlakuan stratifikasi suhu tinggi dengan cara merendam benih pada air suhu $40{ }^{0} \mathrm{C}, \quad 50{ }^{0} \mathrm{C}$, dan $60{ }^{0} \mathrm{C}$ dengan waktu perendaman 5 menit, 10 menit, dan 15 menit pada masing-masing suhu. Perlakuan skarifikasi kimia dilakukan dengan cara merendam benih kecipir ke 
dalam larutan asam kuat $\mathrm{H}_{2} \mathrm{SO}_{4}, \mathrm{HNO}_{3}$, dan $\mathrm{HCl}$ dengan konsentrasi $5 \%, 10 \%$, dan $15 \%$ selama 5 menit, 10 menit, dan 15 menit.

Pengamatan terhadap kadar air dilakukan pada saat setelah panen dan setiap sebelum perlakuan. Pengamatan viabilitas benih dilakukan pada tolok ukur daya berkecambah dan potensi tumbuh maksimal pengamatan daya berkecambah dilakukan dengan menghitung persentase jumlah kecambah normal pada 6 HST sebagai hitungan pertama dan 8 HST sebagai hitungan kedua. Pengamatan potensi tumbuh maksimum dilakukan dengan menghitung jumlah persentase kecambah normal hitungan pertama, jumlah kecambah normal hitungan kedua, serta kecambah abnormal hitungan kedua. Pengamatan vigor benih dilakukan pada tolok ukur indeks vigor, kecepatan tumbuh, dan keserempakan tumbuh. Pengamatan indeks vigor dilakukan dengan menghitung persentase jumlah kecambah normal pada hitungan pertama. Pengamatan kecepatan tumbuh dilakukan berdasarkan jumlah kecambah normal yang dapat tumbuh setiap etmal (24 jam). Pengamatan keserempakan tumbuh dihitung berdasarkan jumlah kecambah normal kuat diantara hitungan pertama dan kedua. Pengamatan histologi dilakukan secara mikroskopis dengan membuat preparat penampang melintang benih pada perlakuan yang memberikan pengaruh nyata. Preparat tiap-tiap perlakuan diamati menggunakan mikroskop kemudian dibandingkan dengan kontrol. Pengamatan morfologi dilakukan terhadap struktur kecambah benih kecipir setiap perlakuan untuk mempelajari pengaruh perlakuan terhadap pertumbuhan kecambah.

\section{HASIL DAN PEMBAHASAN}

Pengamatan kadar air benih menunjukkan bahwa benih kecipir memiliki kadar air rata-rata sebesar $10.93 \%$. Tergolong dalam kadar air yang aman untuk dilakukan penyimpanan mengingat benih kecipir yang tergolong dalam benih ortodoks. Kadar air selama periode penyimpanan merupakan faktor yang sangat penting untuk mempengaruhi masa hidup benih (Widajati et al.,
2013). Ruang penyimpanan benih yang digunakan dalam penelitian merupakan ruang penyimpanan dengan suhu dan kelembaban berkisar antara 17 ${ }^{0} \mathrm{C}-22{ }^{0} \mathrm{C}$ dan $54 \%$ - 62\%. Penyimpanan benih seperti ini bertujuan untuk memperlambat kemunduran benih sampai benih ditanam. Kemunduran benih yang terjadi selama periode penyimpanan dapat diperlambat dengan teknologi penyimpanan yang baik (Widajati et al., 2013). Wadah yang digunakan untuk menyimpan benih adalah toples plastik yang bersifat semi permeabel terhadap udara. Benih telah disimpan selama 5 bulan sebelum penelitian, yaitu mulai bulan September 2015 sampai dengan bulan Januari 2016.

Metode perkecambahan yang digunakan merupakan metode in sand. Rahayu (2015) menyatakan bahwa substrat pasir dengan metode in sand merupakan substrat terbaik untuk media perkecambahan benih kecipir. Pasir merupakan media yang porous sehingga mudah ditembus oleh akar kecambah. Proses pengecambahan dilakukan di dalam rumah kaca dengan suhu, kelembaban, dan intensitas cahaya yang cukup. Utomo (2006) menyatakan bahwa cahaya, suhu, kelembaban merupakan tiga faktor utama yang mempengaruhi perkecambahan.

Hasil analisis ragam pengaruh perlakuan pematahan dormansi terhadap semua peubah yang diamati disajikan pada Tabel 1. Hasil pengamatan menunjukkan bahwa pemberian perlakuan pematahan dormansi pada benih kecipir berpengaruh sangat nyata terhadap hampir semua peubah yang diamati yaitu daya berkecambah $(\%)$, indeks vigor $(\%)$, kecepatan tumbuh (\% etmal $^{-1}$ ), dan keserempakan tumbuh $(\%)$, hanya pada peubah potensi tumbuh maksimal (\%) yang berpengaruh nyata. Hal ini menunjukkan bahwa pemberian perlakuan pematahan dormansi pada benih kecipir mampu memperbaiki vigor dan viabilitas benih. Azad et al. (2012) menyatakan bahwa perlakuan sebelum tanam akan mempengaruhi tingkat perkecambahan dari suatu benih. Salah satu perlakuan sebelum tanam yang umum dilakukan adalah pematahan dormansi.

Tabel 1. Rekapitulasi sidik ragam pengaruh metode pematahan dormansi terhadap parameter viabilitas dan vigor benih

\begin{tabular}{|c|c|}
\hline Tolok Ukur & F value \\
\hline Daya berkecambah (\%) & $7.65 * *$ \\
\hline Indeks Vigor (\%) & $7.40 * *$ \\
\hline Kecepatan tumbuh $\left(\%\right.$ etmal $\left.^{-1}\right)$ & $8.93 * *$ \\
\hline Keserempakan tumbuh (\%) & $8.98 * *$ \\
\hline Potensi tumbuh maksimal (\%) & $1.74 *$ \\
\hline
\end{tabular}

Keterangan : **= berpengaruh sangat nyata; *= berpengaruh nyata berdasarkan uji ANOVA pada taraf nyata $5 \%$. 
Hasil analisis ragam pada Tabel 1 menunjukkan bahwa perlakuan pematahan dormansi memberikan pengaruh yang nyata baik pada parameter viabilitas maupun vigor benih, oleh karena itu dilakukan uji lanjut DMRT untuk mengetahui perlakuan terbaik. Tabel 2. merupakan hasil uji lanjut nilai tengah masingmasing perlakuan pematahan dormansi terhadap viabilitas benih kecipir.

Tabel 2. Nilai tengah masing-masing perlakuan pematahan dormansi terhadap viabilitas benih kecipir

\begin{tabular}{|c|c|c|c|c|c|}
\hline Perlakuan & $\mathrm{DB}(\%)$ & PTM $(\%)$ & Perlakuan & $\mathrm{DB}(\%)$ & PTM $(\%)$ \\
\hline Kontrol & $83.33^{\mathrm{b}-\mathrm{e}}$ & $96.67^{\mathrm{a}}$ & HNO3 $15 \% 15$ menit & $68.33^{g}$ & $86.67^{\mathrm{abc}}$ \\
\hline Amplas & $70.00^{\mathrm{fg}}$ & $80.00^{\mathrm{c}}$ & $\mathrm{HCl} 5 \% 5$ menit & $83.33^{\mathrm{b}-\mathrm{e}}$ & $90.00^{\mathrm{abc}}$ \\
\hline $\mathrm{H} 2 \mathrm{SO} 45 \% 5$ menit & $71.67^{\mathrm{fg}}$ & $85.00^{\mathrm{bc}}$ & $\mathrm{HCl} 5 \% 10$ menit & $86.67^{\mathrm{abc}}$ & $91.67^{\mathrm{ab}}$ \\
\hline $\mathrm{H} 2 \mathrm{SO} 45 \% 10$ menit & $90.00^{\mathrm{ab}}$ & $91.67^{\mathrm{ab}}$ & $\mathrm{HCl} 5 \% 15$ menit & $78.33^{\mathrm{c}-\mathrm{f}}$ & $80.00^{\mathrm{c}}$ \\
\hline $\mathrm{H} 2 \mathrm{SO} 45 \% 15$ menit & $71.67^{\mathrm{fg}}$ & $90.00^{\mathrm{abc}}$ & $\mathrm{HCl} 10 \% 5$ menit & $88.33^{\mathrm{ab}}$ & $91.67^{\mathrm{ab}}$ \\
\hline $\mathrm{H} 2 \mathrm{SO} 410 \% 5$ menit & $83.33^{\mathrm{b}-\mathrm{e}}$ & $96.67^{\mathrm{a}}$ & $\mathrm{HCl} 10 \% 10$ menit & $78.33^{\mathrm{c}-\mathrm{f}}$ & $91.67^{\mathrm{ab}}$ \\
\hline H2SO4 10\% 10 menit & $83.33^{\mathrm{b}-\mathrm{e}}$ & $91.67^{\mathrm{ab}}$ & $\mathrm{HCl} 10 \% 15$ menit & $86.67^{\mathrm{abc}}$ & $93.33^{\mathrm{ab}}$ \\
\hline H2SO4 10\% 15 menit & $75.00^{\text {efg }}$ & $91.67^{\mathrm{ab}}$ & $\mathrm{HCl} 15 \% 5$ menit & $90.00^{\mathrm{ab}}$ & $91.67^{\mathrm{ab}}$ \\
\hline $\mathrm{H} 2 \mathrm{SO} 415 \% 5$ menit & $78.33^{\mathrm{c}-\mathrm{f}}$ & $88.33^{\mathrm{abc}}$ & $\mathrm{HCl} 15 \% 10$ menit & $76.67^{\mathrm{def}}$ & $85.00^{\mathrm{bc}}$ \\
\hline $\mathrm{H} 2 \mathrm{SO} 415 \% 10$ menit & $76.67^{\text {def }}$ & $90.00^{\mathrm{abc}}$ & $\mathrm{HCl} 15 \% 15$ menit & $73.33^{\mathrm{fg}}$ & $88.33^{\mathrm{abc}}$ \\
\hline $\mathrm{H} 2 \mathrm{SO} 415 \% 15$ menit & $83.33^{\mathrm{b}-\mathrm{e}}$ & $90.00^{\mathrm{abc}}$ & suhu $40{ }^{\circ} \mathrm{C} 5$ menit & $90.00^{\mathrm{ab}}$ & $91.67^{\mathrm{ab}}$ \\
\hline HNO3 $5 \% 5$ menit & $71.67^{\mathrm{fg}}$ & $90.00^{\mathrm{abc}}$ & suhu $40{ }^{0} \mathrm{C} 10$ menit & $88.33^{\mathrm{ab}}$ & $91.67^{\mathrm{ab}}$ \\
\hline HNO3 5\% 10 menit & $93.33^{\mathrm{a}}$ & $95.00^{\mathrm{ab}}$ & suhu $40{ }^{0} \mathrm{C} 15$ menit & $78.33^{\mathrm{c}-\mathrm{f}}$ & $90.00^{\mathrm{abc}}$ \\
\hline HNO3 5\% 15 menit & $78.33^{\mathrm{c}-\mathrm{f}}$ & $86.67^{\mathrm{abc}}$ & suhu $50{ }^{\circ} \mathrm{C} 5$ menit & $85.00^{\text {bcd }}$ & $90.00^{\mathrm{abc}}$ \\
\hline HNO3 10\% 5 menit & $88.33^{\mathrm{ab}}$ & $93.33^{\mathrm{ab}}$ & suhu $50{ }^{\circ} \mathrm{C} 10$ menit & $90.00^{\mathrm{ab}}$ & $95.00^{\mathrm{ab}}$ \\
\hline HNO3 $10 \% 10$ menit & $78.33^{\mathrm{c}-\mathrm{f}}$ & $88.33^{\mathrm{abc}}$ & suhu $50{ }^{0} \mathrm{C} 15$ menit & $70.00^{\mathrm{fg}}$ & $90.00^{\mathrm{abc}}$ \\
\hline HNO3 $10 \% 15$ menit & $76.67^{\mathrm{def}}$ & $86.67^{\mathrm{abc}}$ & suhu $60{ }^{\circ} \mathrm{C} 5$ menit & $88.33^{\mathrm{ab}}$ & $95.00^{\mathrm{ab}}$ \\
\hline HNO3 15\% 5 menit & $76.67^{\mathrm{def}}$ & $95.00^{\mathrm{ab}}$ & suhu $60{ }^{0} \mathrm{C} 10$ menit & $83.33^{\mathrm{b}-\mathrm{e}}$ & $95.00^{\mathrm{ab}}$ \\
\hline HNO3 $15 \% 10$ menit & $73.33^{\mathrm{fg}}$ & $90.00^{\mathrm{abc}}$ & suhu $60{ }^{\circ} \mathrm{C} 15$ menit & $83.33^{\mathrm{b}-\mathrm{e}}$ & $90.00^{\mathrm{abc}}$ \\
\hline
\end{tabular}

Keterangan : angka-angka yang diikuti oleh huruf yang sama pada kolom yang sama tidak berbeda nyata pada taraf uji DMRT 5\%

Tabel 3 menyajikan hasil uji lanjut nilai tengah masing-masing perlakuan metode pematahan dormansi terhadap vigor benih kecipir pada beberapa tolok ukur.

Tabel 3. Nilai tengah masing-masing perlakuan pematahan dormansi terhadap vigor benih kecipir

\begin{tabular}{|c|c|c|c|c|c|c|c|}
\hline Perlakuan & IV & Kct & Kst & Perlakuan & IV & Kct & Kst \\
\hline Kontrol & $43.33^{\circ}$ & $12.49^{\mathrm{e}-\mathrm{K}}$ & $70.00^{\text {Dcd }}$ & $\mathrm{HNO}_{3} 15 \% 15$ menit & $46.67^{\mathrm{a}-\mathrm{a}}$ & $10.57^{\mathrm{IIIII}}$ & $51.67^{\mathrm{IJK}}$ \\
\hline Amplas & $50.00^{\mathrm{abc}}$ & $9.94^{\mathrm{n}}$ & $53.33^{\mathrm{n}-\mathrm{K}}$ & $\mathrm{HCl} 5 \% 5$ menit & $45.00^{\mathrm{D}-\mathrm{e}}$ & $12.72^{\mathrm{a}-\mathrm{K}}$ & $65.00^{\mathrm{D}-\mathrm{I}}$ \\
\hline $\mathrm{H}_{2} \mathrm{SO}_{4} 5 \% 5$ menit & $36.67^{\mathrm{a}-\mathrm{n}}$ & $10.93^{\mathrm{IImn}}$ & $60.00^{\mathrm{u}-1}$ & $\mathrm{HCl} 5 \% 10$ menit & $46.67^{\mathrm{d}-\mathrm{a}}$ & $13.44^{\mathrm{D}-1}$ & $65.00^{\mathrm{D}-1}$ \\
\hline $\mathrm{H}_{2} \mathrm{SO}_{4} 5 \% 10$ menit & $45.00^{\mathrm{D}-\mathrm{e}}$ & $13.72^{\mathrm{a}-\mathrm{e}}$ & $70.00^{\mathrm{bca}}$ & $\mathrm{HCl} 5 \% 15$ menit & $45.00^{\mathrm{D}-\mathrm{e}}$ & $12.61^{\mathrm{a}-\mathrm{K}}$ & $65.00^{\mathrm{D}-\mathrm{I}}$ \\
\hline $\mathrm{H}_{2} \mathrm{SO}_{4} 5 \%$ 15menit & $21.67^{\mathrm{J}}$ & $11.47^{\mathrm{KIm}}$ & $51.67^{11 \mathrm{~K}}$ & $\mathrm{HCl} 10 \% 5$ menit & $41.67^{\mathrm{c}-\mathrm{I}}$ & $13.66^{\mathrm{a}-\mathrm{e}}$ & $68.33^{\mathrm{D}-\mathrm{e}}$ \\
\hline $\mathrm{H}_{2} \mathrm{SO}_{4} 10 \% 5$ menit & $35.00^{\mathrm{e}-\mathrm{n}}$ & $12.76^{\mathrm{a}-\mathrm{K}}$ & $61.67^{\mathrm{c}-\mathrm{n}}$ & $\mathrm{HCl} 10 \% 10$ menit & $40.00^{\mathrm{c}-\mathrm{g}}$ & $12.54^{\mathrm{a}-\mathrm{K}}$ & $61.67^{\mathrm{c}-\mathrm{n}}$ \\
\hline $\mathrm{H}_{2} \mathrm{SO}_{4} 10 \% 10$ menit & $36.67^{a-n}$ & $12.91^{\mathrm{a}-1}$ & $65.00^{\mathrm{D}-\mathrm{I}}$ & $\mathrm{HCl} 10 \% 15$ menit & $41.67^{\mathrm{c}-\mathrm{I}}$ & $13.02^{\mathrm{a}-\mathrm{n}}$ & $68.33^{\mathrm{D}-\mathrm{e}}$ \\
\hline $\mathrm{H}_{2} \mathrm{SO}_{4} 10 \% 15$ menit & $28.33^{\mathrm{n} 1 \mathrm{~J}}$ & $11.13^{\mathrm{Imn}}$ & $55.00^{\mathrm{g}-\mathrm{J}}$ & $\mathrm{HCl} 15 \% 5$ menit & $46.67^{\mathrm{a}-\mathrm{a}}$ & $11.53^{\mathrm{J}-\mathrm{m}}$ & $58.33^{\mathrm{e}-1}$ \\
\hline $\mathrm{H}_{2} \mathrm{SO}_{4} 15 \% 5$ menit & $40.00^{\mathrm{c}-\mathrm{g}}$ & $11.93^{\mathrm{g}-\mathrm{I}}$ & $53.33^{\mathrm{n}-\mathrm{K}}$ & $\mathrm{HCl} 15 \% 10$ menit & $36.67^{\mathrm{a}-\mathrm{n}}$ & $11.70^{1-\mathrm{m}}$ & $68.33^{\mathrm{D}-\mathrm{e}}$ \\
\hline $\mathrm{H}_{2} \mathrm{SO}_{4} 15 \% 10$ menit & $45.00^{\mathrm{D}-\mathrm{e}}$ & $12.51^{\mathrm{e}-\mathrm{K}}$ & $70.00^{\mathrm{Dcd}}$ & $\mathrm{HCl} 15 \% 15$ menit & $40.00^{\mathrm{c}-\mathrm{g}}$ & $11.75^{\mathrm{n}-\mathrm{m}}$ & $56.67^{1-\mathrm{J}}$ \\
\hline $\mathrm{H}_{2} \mathrm{SO}_{4} 15 \% 15$ menit & $46.67^{\mathrm{a}-\mathrm{a}}$ & $13.32^{\mathrm{c}-\mathrm{I}}$ & $66.67^{\mathrm{D}-\mathrm{I}}$ & suhu $40{ }^{\circ} \mathrm{C} 5$ menit & $40.00^{\mathrm{c}-\mathrm{g}}$ & $14.50^{\mathrm{abc}}$ & $75.00^{\mathrm{b}}$ \\
\hline $\mathrm{HNO}_{3} 5 \% 5$ menit & $45.00^{\mathrm{D}-\mathrm{e}}$ & $11.57^{1-m}$ & $63.33^{\mathrm{c}-\mathrm{g}}$ & suhu $40{ }^{\circ} \mathrm{C} 10$ menit & $43.33^{\mathrm{D}-\mathrm{e}}$ & $12.67^{\mathrm{a}-\mathrm{K}}$ & $75.00^{\mathrm{D}}$ \\
\hline $\mathrm{HNO}_{3} 5 \% 10$ menit & $50.00^{\mathrm{adc}}$ & $14.67^{\mathrm{ad}}$ & $86.67^{\mathrm{a}}$ & suhu $40{ }^{\circ} \mathrm{C} 15$ menit & $28.33^{\mathrm{IIJ}}$ & $12.59^{\mathrm{a}-\mathrm{K}}$ & $63.33^{\mathrm{c}-\mathrm{g}}$ \\
\hline $\mathrm{HNO}_{3} 5 \% 15$ menit & $51.67^{\mathrm{ab}}$ & $12.84^{\mathrm{a}-\mathrm{J}}$ & $56.67^{\mathrm{I}-\mathrm{J}}$ & suhu $50{ }^{\circ} \mathrm{C} 5$ menit & $43.33^{\mathrm{D}-\mathrm{e}}$ & $13.11^{\mathrm{a}-\mathrm{g}}$ & $70.00^{\mathrm{Dca}}$ \\
\hline $\mathrm{HNO}_{3} 10 \% 5$ menit & $46.67^{\mathrm{a}-\mathrm{a}}$ & $13.86^{\mathrm{a}-\mathrm{a}}$ & $75.00^{\mathrm{D}}$ & suhu $50^{\circ} \mathrm{C} 10$ menit & $50.00^{\mathrm{abc}}$ & $14.79^{\mathrm{a}}$ & $71.67^{\mathrm{bc}}$ \\
\hline $\mathrm{HNO}_{3} 10 \% 10 \mathrm{n}$ & $30.00^{\mathrm{g}-\mathrm{J}}$ & $12.19^{\mathrm{I}-\mathrm{K}}$ & $48.33^{\mathrm{JK}}$ & suhu $50^{\circ} \mathrm{C} 15$ menit & $25.00^{1]}$ & $10.22^{\mathrm{n}}$ & $46.67^{\mathrm{K}}$ \\
\hline $\mathrm{HNO}_{3} 10 \% 15$ menit & $56.67^{\mathrm{a}}$ & $11.92^{\mathrm{g}-1}$ & $66.67^{\mathrm{D}-\mathrm{I}}$ & suhu $60^{\circ} \mathrm{C} 5$ menit & $25.00^{1]}$ & $13.45^{\mathrm{D}-\mathrm{I}}$ & $75.00^{\mathrm{D}}$ \\
\hline $\mathrm{HNO}_{3} 15 \% 5$ menit & $31.67^{\mathrm{I}-1}$ & $11.60^{1-m}$ & $65.00^{\mathrm{D}-\mathrm{I}}$ & suhu $60{ }^{\circ} \mathrm{C} 10$ menit & $46.67^{\mathrm{a}-\mathrm{a}}$ & $13.41^{\mathrm{D}-\mathrm{I}}$ & $75.00^{\mathrm{D}}$ \\
\hline $\mathrm{HNO}_{3} 15 \% 10$ menit & $43.33^{\mathrm{b}-\mathrm{e}}$ & $11.09^{\mathrm{Imn}}$ & $60.00^{\mathrm{d}-1}$ & suhu $60^{\circ} \mathrm{C} 15$ menit & $36.67^{d-h}$ & $11.77^{\mathrm{g}-\mathrm{m}}$ & $53.33^{\mathrm{h}-\mathrm{k}}$ \\
\hline
\end{tabular}

Keterangan : angka-angka yang diikuti oleh huruf yang sama pada kolom yang sama tidak berbeda nyata pada taraf uji DMRT 5\% 
Pengaruh Pematahan Dormansi dengan Asam Kuat terhadap Viabilitas Benih Kecipir

Hasil uji lanjut pada tolok ukur daya berkecambah pada Tabel 2 menunjukkan adanya perbedaan yang cukup signifikan antara benih kontrol dengan benih yang mendapatkan perlakuan, dimana kontrol menghasilkan daya berkecambah yang lebih rendah dibandingkan beberapa perlakuan asam kuat. Hal ini mengindikasi bahwa metode pematahan dormansi dengan perlakuan asam kuat dapat meningkatkan viabilitas potensial benih kecipir pada tolok ukur daya berkecambah. Daya berkecambah yang dihasilkan pada perlakuan asam kuat $\mathrm{HNO}_{3} 5 \%$ selama 10 menit adalah $93.33 \%$ yang merupakan daya berkecambah tertinggi dibandingkan dengan kontrol maupun perlakuan lain, dimana kontrol hanya menghasilkan daya berkecambah $83.33 \%$, sedangkan perlakuan asam kuat $\mathrm{H}_{2} \mathrm{SO}_{4} 5 \%$ selama 10 menit, $\mathrm{HNO}_{3} 10 \%$ selama 5 menit, $\mathrm{HCl} 5 \%$ selama 10 menit, $\mathrm{HCl} 10 \%$ selama 5 menit, HCL $10 \%$ selama 15 menit, dan $\mathrm{HCl} 15 \%$ selama 5 menit merupakan perlakuan asam kuat yang tidak berbeda nyata baik terhadap perlakuan $\mathrm{HNO}_{3} 5 \%$ selama 10 menit sebagai perlakuan terbaik maupun kontrol.

Perlakuan asam kuat $\mathrm{HNO}_{3} 5 \%$ selama 10 menit mampu meningkatkan nilai daya berkecambah benih kecipir. Hal ini disebabkan oleh adanya aktivitas asam $\left(\mathrm{HNO}_{3}\right)$ yang membuat kulit benih menjadi lunak dan benih kehilangan lapisan yang impermeabel terhadap air dan gas, sehingga metabolisme dapat berjalan dengan baik dan benih dapat berkecambah lebih cepat. Peningkatan permeabilitas pada permukaan kulit benih disebabkan oleh larutnya sebagian komponen lignin kulit benih, sehingga air lebih mudah masuk ke dalam benih untuk merangsang pertumbuhan embrio pada proses perkecambahan. Sadjad (1975) menyatakan bahwa perlakuan pematahan dormansi dengan asam kuat berpengaruh terhadap penguraian lignin yang menyusun komponen dinding sel sehingga dengan adanya penguraian lignin maka kulit benih akan menjadi permeabel terhadap air dan gas. Tabel 2 juga menunjukkan bahwa perlakuan $\mathrm{HNO}_{3} 15 \%$ 15 menit merupakan perlakuan dengan nilai daya berkecambah $68.33 \%$, yang artinya lebih rendah dari kontrol dan standar mutu fiologi benih. Hal ini terjadi karena adanya perlakuan yang terlalu berlebihan dalam hal konsentrasi dan durasi perendaman dapat menyebabkan kematian pada benih. Peristiwa over treatment akan menyebabkan rusaknya embrio sehingga benih tidak dapat berkecambah atau mati. Peristiwa over treatment menyebabkan zat asam masuk ke dalam benih dan merusak embrio sehingga menyebabkan benih tidak berkecambah atau mati.

Metode pematahan dormansi dengan perlakuan asam kuat tidak menunjukkan perbedaan yang signifikan terhadap viabilitas total benih kecipir pada tolok ukur potensi tumbuh maksimal (PTM). Hal ini terlihat dari nilai PTM terbaik hanya pada perlakuan $\mathrm{H}_{2} \mathrm{SO}_{4} 10 \%$ selama 5 menit dan kontrol sedangkan perlakuan lain menunjukkan nilai yang tidak berbeda nyata ataupun lebih rendah. Hal ini karena potensi tumbuh maksimum merupakan tolok ukur yang lemah dalam pengujian viabilitas benih. Benih memenuhi kriteria ini walaupun tidak tumbuh kecambah normal dan hanya menunjukkan sedikit gejala pertumbuhannya. Persentase PTM yang tinggi pada benih kontrol mengindikasi bahwa lot benih yang digunakan merupakan lot benih yang masih baik karena memiliki viabilitas yang cukup tinggi selaras dengan nilai daya berkecambah. Ilyas (2012) menyatakan bahwa viabilitas merupakan sifat benih yang menunjukkan daya hidup benih untuk berkecambah.

\section{Pengaruh Pematahan Dormansi dengan Suhu Tinggi terhadap Viabilitas Benih Kecipir}

Hasil uji lanjut pada Tabel 2 menunjukkan bahwa perlakuan suhu tinggi yang dilakukan pada percobaan belum dapat memperbaiki viabilitas benih kecipir. Baik pada tolok ukur daya berkecambah maupun potensi tumbuh maksimal menunjukkan hasil yang tidak berbeda secara signifikan antara kontrol dengan benih yang mendapat perlakuan.

Perlakuan perendaman benih pada suhu tinggi berfungsi untuk melunakkan kulit benih dan memudahkan proses penyerapan air oleh benih sehingga proses-proses fisiologi dalam benih dapat berlangsung untuk proses perkecambahan. Suhu yang tepat dan kondisi lingkungan yang memadai akan memudahkan benih memecahkan dormansinya dan mulai tumbuh. Hasil uji lanjut nilai tengah tolok ukur daya berkecambah dan potensi tumbuh maksimal (Tabel 2.) pada perlakuan suhu $40{ }^{\circ} \mathrm{C}$ sampai $60{ }^{\circ} \mathrm{C}$ dengan waktu 5-15 menit menunjukkan hasil yang tidak signifikan bahkan menurun dibandingkan dengan kontrol. Perlakuan suhu $40{ }^{0} \mathrm{C} 5$ menit, $40{ }^{\circ} \mathrm{C} 10$ menit, $50{ }^{\circ} \mathrm{C} \quad 10$ menit, dan $60{ }^{\circ} \mathrm{C} 5$ menit merupakan perlakuan yang tidak berbeda nyata baik terhadap perlakuan terbaik $\left(\mathrm{HNO}_{3} 5 \%\right.$ selama 10 menit) maupun kontrol, sedangkan perlakuan suhu $50{ }^{\circ} \mathrm{C} 15$ menit merupakan perlakuan yang tidak berbeda nyata dengan perlakuan terendah $\left(\mathrm{HNO}_{3} \quad 15 \% 15\right.$ menit). Hal ini diduga karena perlakuan suhu $40{ }^{\circ} \mathrm{C}$ sampai $60{ }^{\circ} \mathrm{C}$ dengan waktu 
5-15 menit belum mampu mengurai kandungan tanin dan lignin yang terdapat pada kulit benih, sehingga proses penyerapan air melalui imbibisi masih terhalang menyebabkan mekanisme perkecambahan terhambat. Suhu yang tidak sesuai juga dapat menyebabkan aktivitas enzim dalam benih tidak optimal bahkan menyebabkan enzimenzim dalam benih rusak dan embrionya akan mati (Isnaeni dan Habibah, 2014).

Pengaruh Pematahan Dormansi dengan Asam Kuat terhadap Vigor Benih Kecipir

Tabel 3. menyajikan uji lanjut nilai tengah vigor benih dalam tiga tolok ukur yaitu indeks vigor, kecepatan tumbuh, dan keserempakan tumbuh. Tolok ukur indeks vigor menunjukkan bahwa perlakuan $\mathrm{HNO}_{3}$ 10\% 15 menit merupakan perlakuan dengan nilai indeks vigor $56.56 \%$ yang lebih tinggi dan berbeda nyata terhahap kontrol yaitu 43,33\%. Perlakuan $\mathrm{H}_{2} \mathrm{SO}_{4} \quad 15 \% 5$ menit, $\mathrm{HNO}_{3} 5 \% 10$ menit, $\mathrm{HNO}_{3} 5 \% 15$ menit, $\mathrm{HNO}_{3}$ $10 \% 5$ menit, $\mathrm{HNO}_{3} 15 \% 15$ menit, dan $\mathrm{HCl} 15 \%$ 5 menit merupakan perlakuan asam kuat yang tidak berbeda nyata terhadap perlakuan terbaik dan kontrol. Indeks vigor merupakan salah satu tolok ukur yang sangat kuat. Nilai indeks vigor diperoleh dari benih-benih yang telah tumbuh menjadi kecambah normal pada hitungan pertama, sehingga hanya benih-benih yang memiliki vigor tinggi yang mampu memenuhi kriteria ini. Hal ini yang menyebabkan perlakuan pematahan dormansi memberikan pengaruh yang lebih beragam terhadap hasil pengujian. Tolok ukur kecepatan tumbuh menunjukkan bahwa perlakuan $\mathrm{HNO}_{3} 5 \% 10$ menit, $\mathrm{H}_{2} \mathrm{SO}_{4} 5 \% 10$ menit, $\mathrm{HNO}_{3}$ $10 \% 5$ menit, dan $\mathrm{HCl} 10 \% 5$ menit merupakan perlakuan asam kuat yang mempunyai nilai kecepatan tumbuh yang tidak berbeda nyata dengan perlakuan terbaik (suhu $50{ }^{\circ} \mathrm{C} 10$ menit) dan memberikan nilai kecepatan tumbuh yang lebih baik dibandingkan dengan kontrol. Hal ini menunjukkan bahwa perlakuan asam kuat mampu memperbaiki vigor benih melalui kecepatan tumbuhnya. Benih yang mempunyai kecepatan perkecambahan yang tinggi menunjukkan bahwa benih tersebut memiliki vigor yang tinggi dan akan menghasilkan tanaman yang tahan terhadap keadaan lingkungan (Kartasapoetra, 2003). Tolok ukur keserempakan tumbuh pada Tabel 3 menunjukkan bahwa perlakuan $\mathrm{HNO}_{3} \quad 5 \% 10$ menit merupakan perlakuan dengan nilai keserepakan tumbuh $86.67 \%$, yang lebih tinggi secara signifikan dibandingkan dengan kontrol dengan nilai $70.00 \%$. Hal ini menunjukkan bahwa perlakuan $\mathrm{HNO}_{3} \quad 5 \% \quad 10$ menit mampu memperbaiki vigor benih baik melalui kecepatan tumbuh maupun keserempakan tumbuh. Sadjad et al. (1999) menyatakan bahwa disamping memiliki vigor yang tinggi, benih dituntut untuk dapat cepat tumbuh. Homogenitas perkecambahan diawali oleh keserempakan perkecambahan benih sehingga selain cepat tumbuh, benih dengan vigor tinggi juga harus tumbuh serempak.

Mekanisme yang terjadi pada peristiwa perendaman benih dalam asam kuat yaitu asam kuat memfasilitasi larutnya kandungan lignin pada benih sehingga benih bercelah. Celah yang terbentuk menyebabkan air mudah masuk sehingga benih mudah berkecambah. Pernyataan ini sesuai dengan hasil perlakuan $\mathrm{HNO}_{3} 5 \% \quad 10$ menit untuk tolok ukur kecepatan tumbuh dan keserempakan tumbuh serta perlakuan $\mathrm{HNO}_{3} 10 \%$ 15 menit untuk tolok ukur indeks vigor, dimana ketiga tolok ukur tersebut merupakan tolok ukur yang mewakili vigor benih. Hal tersebut menunjukkan bahwa asam kuat khususnya $\mathrm{HNO}_{3}$ pada konsentrasi dan lama perendaman yang optimal dapat meningkatkan vigor benih sebagai metode pematahan dormansi benih kecipir. Pematahan dormansi dengan larutan asam $\mathrm{HNO}_{3}$ apabila dilakukan dengan konsentrasi dan waktu perendaman yang tidak sesuai akan menyebabkan rusaknya embrio dan menyebabkan benih tersebut tidak dapat tumbuh. Hal ini seperti yang terjadi pada perlakuan $\mathrm{H}_{2} \mathrm{SO}_{4} 5 \% 15$ menit pada tolok ukur indeks vigor, perlakuan $\mathrm{HNO}_{3} 15 \% 15$ menit pada tolok ukur kecepatan tumbuh, dan perlakuan $\mathrm{HNO}_{3} \quad 10 \% \quad 10$ menit pada tolok ukur keserempakan tumbuh. Kerusakan pada kulit benih yang disebabkan oleh asam kuat menyebabkan zat asam tersebut masuk ke dalam benih dan merusak embrio.

\section{Pengaruh Pematahan Dormansi dengan Suhu Tinggi terhadap Vigor Benih Kecipir}

Hasil uji lanjut nilai tengah (Tabel 3) menunjukkan bahwa perlakuan suhu tinggi tidak berpengaruh secara yang signifikan terhadap tolok ukur indeks vigor. Perlakuan suhu $50{ }^{\circ} \mathrm{C} 10$ menit dan suhu $60{ }^{\circ} \mathrm{C} 10$ menit merupakan perlakuan yang hasilnya tidak berbeda secara nyata terhadap perlakuan terbaik maupun kontrol. Tolok ukur keserempakan tumbuh juga menunjukkan hal yang serupa dimana perlakuan suhu $40^{\circ} \mathrm{C} 5$ menit, suhu $40{ }^{0} \mathrm{C} 10$ menit, suhu $60{ }^{\circ} \mathrm{C} 5$ menit, dan suhu $60{ }^{\circ} \mathrm{C} 10$ menit memberikan hasil yang tidak berbeda nyata terhadap kontrol maupun perlakuan lain. Berbeda dengan dua tolok ukur sebelumnya, pada tolok ukur kecepatan tumbuh perlakuan suhu $50{ }^{0} \mathrm{C} 10$ menit memberikan hasil yang berbeda secara signifikan terhadap kontrol dan perlakuan lainnya. Perlakuan suhu $50 \quad{ }^{0} \mathrm{C} \quad 10 \quad$ menit 
mempunyai nilai kecepatan tumbuh sebesar $14.79 \%$ etmal $^{-1}$ sedangkan kontrol hanya $12,49 \%$ etmal $^{-1}$.

Perlakuan pematahan dormansi dengan cara merendam benih pada suhu yang tinggi bertujuan untuk melunakkan kulit benih sehingga memudahkan proses penyerapan air, dengan adanya air yang masuk maka proses-proses fisiologi untuk berkecambah dapat berlangsung. Biji yang direndam dalam air dengan suhu tinggi memungkinkan terurainya kandungan tanin dan lignin yang terdapat pada kulit benih sehingga benih menjadi lebih lunak sehingga imbibisi mudah terjadi (Puspitarini, 2003). Pernyataan ini mendukung hasil dari perlakuan suhu $50{ }^{0} \mathrm{C} 10$ menit dengan nilai kecepatan tumbuh yang lebih baik dibangding kontrol maupun perlakuan lain, sehingga dapat dikatakan bahwa perlakuan suhu $50{ }^{0} \mathrm{C} 10$ menit dapat meningkatkan vigor benih pada tolok ukur kecepatan tumbuh. Penentuan suhu dan waktu perendaman yang optimum sebagai perlakuan pematahan dormansi benih kecipir sangat penting. Penggunaan suhu yang terlalu tinggi dan waktu perendaman yang terlalu lama dapat menyebabkan enzim-enzim dalam benih akan rusak dan embrionya akan mati. Hal ini seperti yang terjadi pada perlakuan suhu $50{ }^{\circ} \mathrm{C}$ selama 15 menit, perlakuan tersebut memberikan hasil terburuk pada ketiga tolok ukur vigor benih.

\section{Pengaruh Pematahan Dormansi dengan} Skarifikasi Mekanik terhadap Viabilitas dan Vigor Benih Kecipir

Benih yang diberi perlakuan skarifikasi mekanis dengan diamplas memungkinkan masuknya air ke dalam benih lebih mudah sehingga imbibisi sebagai proses awal perkecambahan dapat terjadi. Hasil uji lanjut nilai tengah menunjukkan bahwa perlakuan skarifikasi mekanis menggunakan amplas memberikan hasil yang lebih buruk dibandingan kontrol pada tolok ukur daya berkecambah dan potensi tumbuh maksimum sebagai variabel viabilitas serta kecepatan tumbuh dan keserempakan tumbuh pada variabel vigor benih, sedangkan pada tolok ukur indeks vigor perlakuan amplas memberikan hasil yang lebih baik tetapi tidak berbeda secara signifikan terhadap kontrol. Hasil tersebut menunjukkan bahwa perlakuan amplas belum mampu menaikkan baik viabilitas maupun vigor benih kecipir. Benih kecipir yang diamplas sebagian besar bagian bijinya yang keras akan hilang. Hal ini menyebabkan endosperm benih semakin terbuka lebar sehingga semakin luas kontak dengan lingkungan sekitar. Endosperm yang terbuka akan memiliki resiko yang lebih tinggi terhadap patogen-patogen yang dapat masuk ke dalam benih, terutama cendwan yang mudah tumbuh dan mengambil zat-zat yang dibutuhkan embrio untuk hidup. Pertumbuhan jamur yang lebih cepat akan menghambat perkecambahan, menyebabkan benih menjadi kering, busuk, dan mati.

Pengaruh Pematahan Dormansi dengan Asam Kuat terhadap Struktur Testa Benih Kecipir

Asam kuat merupakan salah satu zat kimia yang mampu meningkatkan persentase perkecambahan pada benih yang memiliki dormansi kulit benih keras seperti kecipir. Hal ini disebabkan oleh adanya aktivitas asam yang membuat kulit benih menjadi lunak dan benih kehilangan lapisan yang impermeabel terhapat air dan gas. Peningkatan permeabilitas pada permukaan kulit benih disebabkan oleh larutnya sebagian komponen lignin kulit benih. Pengamatan histologi yang dilakukan secara mikroskopis terhadap permukaan kulit benih menunjukkan bahwa larutan asam kuat dapat mempengaruhi struktur permukaan kulit benih kecipir. Terlihat bahwa terjadi perubahan struktur pada bagian epidermis, hipodermis, dan parenkim. Epidermis adalah lapisan terpenting karena merupakan lapisan kulit terluar benih, sehingga menjadi penentu berhasil tidaknya air masuk ke dalam benih dan dilapisi oleh lignin dan kitin membentuk kutikula (Shao et al., 2007). Lapisan epidermis tersusun atas jaringan palisade (jaringan tiang) yang di dalamnya terdapat sebuah lapisan light line yang berfungsi sebagai pengatur proses imbibisi ke dalam benih (Krisnawati dan Adie, 2008).

Larutan asam kuat ( $\left.\mathrm{HNO}_{3}\right)$ dapat melarutkan komponen lignin pada bagian epidermis benih kecipir yang tersusun atas jaringan palisade. Jaringan palisade merupakan jaringan yang berbentuk tongkat/batang dengan sel-sel yang mengalami penebalan sekunder oleh lignin, tersusun membentuk lapisan kontinyu pada testa benih. Larutnya lignin menciptakan celah pada lapisan light line sehingga meningkatkan permeabiltas benih. Krisnawati dan Adie (2008) melaporkan bahwa pada biji legum yang berkulit keras, light line juga bersifat impermeabilitas tinggi. Asam kuat yang telah menembus lapisan epidermis dapat menyusutkan lapisan hipodermis dan jaringan parenkim. Lapisan hipodermis merupakan lapisan dibawah sel-sel epidermis yang berbeda baik morfologi maupun fisiologinya dengan lapisan di atasnya. Neto (2000) menjelaskan bahwa asam kuat bekerja pada bagian kutikula yang melarutkan lignin sehingga 
kulit menjadi lunak dan air maupun gas dapat masuk ke dalam benih sehingga terjadi perkecambahan.

Pengaruh Pematahan Dormansi dengan Suhu Tinggi terhadap Struktur Testa Benih Kecipir

Perlakuan pematahan dormansi benih dengan merendam benih dalam air suhu tinggi berfungsi untuk melunakkan kulit benih sehingga memudahkan proses penyerapan air oleh benih. Air dengan suhu tinggi dapat mematahkan dormansi fisik seperti yang terdapat pada benih kecipir melalui mekanisme perbedaan tegangan yang disebabkan oleh perubahan suhu yang terjadi secara cepat. Perbedaan tegangan tersebut menyebabkan timbulnya celah diantara jaringan palisade yang terdapat pada epidermis benih sehingga air dan gas dapat masuk ke dalam benih. Pengamatan histologi menunjukkan bahwa perlakuan suhu tinggi menyebabkan jaringan palisade yang tersusun atas komponen lignin pada lapisan epidermis benih menyusut sehingga menimbulkan celah akibat adanya perlakuan suhu tinggi. Suhu air yang tinggi memungkinkan terurainya kandungan tanin dan lignin yang terdapat pada kulit benih. Lapisan hipodermis dan jaringan parenkim yang terdapat di bawah epidermis juga memampat sehingga memudahkan air dan gas masuk ke dalam benih menuju embrio. Menurut Schmidht (2002), air panas mematahkan dormansi fisik pada Leguminoseae melalui tegangan yang menyebabkan pecahnya jaringan palisade yang mengandung lapisan light line yang bersifat impermeabel. Krisnawati dan Adie (2008) berpendapat bahwa metabolisme pada interaksi suhu dan lama perendaman mampu menyerap air lebih cepat, melunakkan kulit benih dan meningkatkan respirasi benih sehingga membantu kegiatan sel dan enzim.

\section{Pengaruh Perlakuan Pematahan Dormansi terhadap Struktur Kecambah Benih Kecipir}

Tipe perkecambahan benih kecipir termasuk dalam tipe perkecambahan hipogeal yang ditandai dengan terjadinya pembentangan ruas batang teratas (epikotil) sehingga daun lembaga ikut tertarik ke atas tanah, tetapi kotiledon tetap dibawah tanah. Perlakuan asam kuat $\mathrm{HNO}_{3}$ 5\% selama 10 menit merupakan perlakuan yang dapat meningkatkan viabilitas maupun vigor benih melalui tolok ukur daya berkecambah dan keserempakan tumbuh, sedangkan perlakuan suhu $50{ }^{\circ} \mathrm{C}$ selama 10 menit merupakan perlakuan yang mampu memperbaiki vigor benih pada tolok ukur kecepatan tumbuh.
Pengamatan pada morfologi kecambah kecipir menunjukkan bahwa perkecambahan benih kecipir dengan perlakuan asam kuat $\mathrm{HNO}_{3} 5 \%$ selama 10 menit terlihat lebih baik dibandingan kontrol maupun perlakuan lain, sedangkan pada perlakuan amplas perkecambahan terlihat lebih buruk dibandingkan dengan kontrol. Hal ini terjadi karena banyaknya benih yang terserang cendawan pada perlakuan amplas.

Pemberian perlakuan suhu yang tepat menyebabkan proses perkecambahan akan berlangsung lebih cepat dan menghasilkan akar yang lebih panjang. Hal ini dikarenakan panjang akar dipengaruhi oleh kecepatan perkecambahan benih. Isnaeni dan Habibah (2014) juga mengungkapkan bahwa perlakuan perendaman suhu yang optimal mempengaruhi waktu munculnya kecambah, persentase perkecambahan, panjang radikula, dan jumlah akar cabang. Pengamatan kecambah kecipir menunjukkan bahwa kecambah dengan perlakuan perendaman air suhu $50{ }^{\circ} \mathrm{C}$ selama 10 menit menghasilkan akar yang lebih panjang dibandingkan dengan kontrol maupun perlakuan lain, dimana perlakuan $50{ }^{\circ} \mathrm{C}$ selama 10 menit merupakan perlakuan dengan nilai kecepatan tumbuh terbaik. Benih yang berkecambah lebih cepat akan menghasilkan bibit yang lebih baik dari pada yang berkecambah lambat.

\section{KESIMPULAN}

Metode pematahan dormansi dengan perlakuan larutan asam kuat $\mathrm{HNO}_{3} 5 \%$ selama 10 menit dengan nilai daya berkecambah $93.33 \%$ dan keserempakan tumbuh $86.67 \%$ merupakan nilai yang nyata lebih baik dibanding kontrol sehingga metode ini dapat meningkatkan persentase daya berkecambah dan keserempakan tumbuh benih kecipir. Perlakuan larutan asam kuat $\mathrm{HNO}_{3} 10 \%$ selama 15 menit dengan nilai indeks vigor $56.67 \%$ merupakan perlakuan yang dapat meningkatkan persentase indeks vigor benih kecipir. Perlakuan suhu $50 \quad{ }^{0} \mathrm{C}$ selama 10 menit dengan nilai kecepatan tumbuh $14.79 \%$ etmal $^{-1}$ merupakan perlakuan yang dapat meningkatkan kecepatan tumbuh dan menghasilkan kecambah dengan akar yang lebih panjang dibandingkan kontrol maupun perlakuan lain. Perlakuan amplas tidak dapat meningkatkan viabilitas maupun vigor benih, bahkan menimbulkan pertumbuhan cendawan yang menyebabkan kemunduran benih.

\section{DAFTAR PUSTAKA}

Astari, R.P., Rosmayati, E.S., Bayu. 2014. Pengaruh pematahan dormansi secara 
fisik dan kimia terhadap kemampuan berkecambah mucuna (Mucuna barcteata D.C). Jurnal Online Agroekoteknologi. 2(2): 803-812.

Azad, M.S., R.K. Biswas, M.A. Matin. 2012. Seed germination of Albizia procera (Roxb.) benth in Bangladesh: a basis for seed source variation and pre-sowing treatment effect. For.Stud.China. 14(2): 124-130.

Ilyas, S. 2012. Ilmu dan Teknologi Benih, Teori dan Hasil-hasil Penelitian. Bogor (ID): PT Penerbit IPB Press.

Isnaeni, E., N.A. Habibah. 2014. Efektifitas skarifikasi dan suhu perendaman terhadap perkecambahan biji kepel [Stelechocarpus burahol (Blume) Hook.F \& Thompson] secara in vitro dan ex vitro. Jurnal MIPA. 37(2): 105-114.

Kartasapoetra, A.G. 2003. Teknologi benih pengolahan benih dan tuntunan praktikum. Jakarta (ID): Rineka Cipta.

Krisnawati, A., M.M. Adie. 2008. Ragam karakter morfologi kulit biji beberapa genotip plasmanutfah kedelai. Balai Penelitian Tanaman Kacang-kacangan dan Umbiumbian. Buletin Plasma Nutfah 14(1): 1418.

Neto, J.C. 2000. Germinatif pretreatment to dormancy break in Guazuma ulmifoia Lamk. seed. Jurnal Scientia Forestalis. 58: $15-24$.

Puspitarini, D.P., 2003. Struktur benih dan dormansi pada benih panggal buaya (Zanthoxylum rhetsa (Roxb) D.C.). [Tesis]. Program Pascasarjana. Institut Pertanian Bogor. Bogor.

Rahayu, A.D. 2015. Pengamatan uji daya berkecambah, optimalisasi substrat perkecambahan dan pematahan dormansi benih kecipir (Psophocarpus tetragonolobus (L.) DC). [Skripsi].
Departemen Agronomi dan Hortikultura. Fakultas Pertanian. Institut Pertanian Bogor. Bogor.

Sadjad, S., M. Endang, S. Ilyas. 1999. Parameter Pengujian Vigor Benih dari Komperatif ke Simulatif. Jakarta (ID): PT Grasindo dan PT Sang Hyang Seri.

Sadjad, S., S. Hari, S.H. Sri, S. Jusup, Sugihharsono, Sudarsono. 1975. DasarDasar Teknologi Benih. Biro Penataran. Institut Pertanian Bogor. Bogor.

Serrato-Valenti, G., L. Cornara, M. Ferrando, P. Modenesi. 1993. Structural and histochemical features of Stylosanthes scaba (Leguminosae; Papilionoideae) seed coat as related to water entry. Canadian Journal of Botani. 71:834-840.

Shao, S.S., C.J. Meyer, F. Ma, C.A. Peterson, M.A. Bernards. 2007. The outermost cuticle of soybean seeds: Chemical composition and function during imbibition. Jounal of Exp. Botany. 58(5):1-12.

Schmit, L. 2002. Pedoman penanganan benih kehutanan. Terjemahan Fransiskus Harum. Direktorat Jendral Rehabilitasi Lahan dan Perhutanan Sosial. Departemen Kehutanan. Jakarta.

Utomo, B. 2006. Ekologi benih. Karya Ilmiah. Fakultas Pertanian. Universitas Sumatera Utara. Medan.

Widajati, E., E. Murniati, E.R. Palupi, T. Kartika, M.R. Suhartanto, A. Qodir. 2013. Dasar Ilmu dan Teknologi Benih. Bogor (ID): IPB Press.

Widhityarini, D., M.W. Suyadi, A. Purwantoro. 2011. Pematahan dormansi benih tanjung (Mimusops elengi L.) dengan skarifikasi dan perendaman kalium nitrat. Fakultas Pertanian. Universitas Gajah Mada. Yogyakarta. 